\title{
An Empirical Investigation of the Impact of Technological Factors on Computer - Based Information Systems (CBIS) Usage by Managers in Banking Sector in Sudan
}

\author{
Nawal Abdalla Adam, Associate Professor \\ Department of Business Administration, Faculty of Business and Administration, Princess \\ Nourah Bint Abdulrahman University, Saudi Arabia \\ E-mail: Nawal_ama@yahoo.com
}

Received: June 14, 2015 Accepted: July 15, 2015 Published: July 19, 2015

doi:10.5296/jsss.v3i1.7819 URL: http://dx.doi.org/10.5296/jsss.v3i1.7819

\begin{abstract}
Computers are becoming more available in Sudanese banks with more sophisticated software and advanced information systems. But factors that might affect acceptance and utilization of these systems by managers need to be examined. This paper seeks to assess the influence of technological factors on computer-based information systems usage by managers in Sudanese banks with reference to the Technology Acceptance Model (TAM). A questionnaire was distributed to a sample of 120 randomly selected middle level managers from different banks in Khartoum State and Gezira State in Sudan. Linear and multiple regression analysis and $\chi 2$ (chi - square) tests were conducted to determine the relationship between the dependent research variable (computer- based information system usage) and the independent research variables (perceived ease of use, perceived usefulness, manager involvement in system design and implementation, and availability of technical support). Findings of this study suggest that the perceived ease of using the system (PEOU) and the perceived usefulness of the system (PU) have significant influence on the computer- based information system usage by banks' managers. The empirical evidence also proved that the perceived ease of use and the perceived usefulness were fully mediating the influence of the technological factors (manager involvement in system design and implementation and technical support). The academic and practical implications of the study were discussed and suggestions for future
\end{abstract}


research was presented.

Keywords: Computer- based information systems, Technological factors, Banking sector, Technology Acceptance Model (TAM)

\section{Introduction}

Information technology made a radical change in the way banking is done over the last years. It enables banks in meeting such exclusive standards of services equired by customers who are have technological awareness contrasted with their partners of the previous years. However, banking is information intensive activity that relies largely computer- based information systems to acquire, process, and deliver the information to all relevant users. Computer- based information systems (CBIS) can provide the managers with accurate and prompt information for decision making (Milicic, 1998). A long these lines, information systems can be considered as a vital part in a wide range of operations in banks (Ravicandran \& Banerjee, 2002).

Many researches have been made on information systems success in organizations. But it is noticed that little research had been undertaken on the factor affecting CBIS usage by managers in banks. One of the factors that affect CBIS usage is the technological factors. Figuring out what is the impact of technological factors on CBIS usage by managers is of a great importance especially in developing countries like Sudan. Studies considered the influence of technological factors together with different variables. Hussein and Selamat (2005), for example, considered the impact of technological factors and organizational factors on information systems success in the electronic government context in Malaysia. Brown (2002) studied the impact of technological and individual factors on perceived ease of use of web- based learning technology in developing countries. However Hussein and Selamat, (2005) investigated the influence of technological factors on information systems success in the electronic-government contexon using Delone and McLean's information system success dimensions model.

According to Trice and Treacy (1988) when determinants of system usage behavior are not well understood, it better for researchers to explain such behavior by referring to an appropriate reference theory. One of models used to explain how the individual is going to accept and utilize the information systems is the Technology Acceptance Model (TAM). This study examined the influence of technological factors on CBIS usage by managers in Sudanese banks with reference to Technology Acceptance Model (TAM); through examining the relationship between the technological factors, perceived ease of use, perceived usefulness, and computer- based information system usage.

\section{Research Methodology}

\subsection{Research Model and Hypothesis}

The framework of this research was based on the Technology Acceptance Model (TAM) which was derived by Davis (1989) and Davis, Bagozzi, and Warshaw, (1989) and based on the theory of reasoned action (TRA) (Ajzen \& Fishbein, 1980). According to TAM system's perceived usefulness (PU) and perceived ease of use (PEOU) are the main predecessors of user attitude toward the system (A) and they are, in turn, influenced by certain external factors (technological, Individual, and organizational factors). It also assumed that system's 


\section{Ml Macrothink}

PU and user's attitude toward the system jointly can determine a user's behavioral intention (BI) to use the specific system. However, PEOU might has an effect on PU. Because TAM aimed mainly at explaining the impact of external factors on systems' usage (Davis \& Bagozzi, 1989), it was used as a reference model to identify the impact of technological factors on computer- based information usage. TAM was found to have better predictive power compared to other information technology models (Tylor \& Todd, 1995) and the most widely accepted model used to understand end-user adoption and acceptance of information technology (Davis, 1989; Davis, Bagozzi, \& Warshaw, 1989). However, some other researchers concluded that TAM's fundamental constructs (PU, PEOU, Attitudes, and BI) do not don't completely mirror the particular effects of context factors that may modify the users' acceptance (Moon \& Kim, 2001).

The framework (Figure 1) suggested that a manager's actual usage of computer- based information system is determined by two factors. They are (1) Perceived ease of use (PEOU) which is the extent to which a manager believes that using and utilizing a certain system would be free of exertion; (2) perceived usefulness $(P U)$, the degree to which a manager believes that using and utilizing a certain system would improve his occupation execution."; PEOU and PU, in turn, affected by particular external factors.

According to Dishaw and Strong (1999) technology features such as user's know - how with the technology, and the fit between task and technology can have a great influence on user's usage. User involvement in developing information systems is a component of successful information technology initiatives (Grover et al., (1995), Jiang, Chen, and Klein (2002), Wixom, and Watson (2001). It also provides a common architecture to share information technology investment information for users.

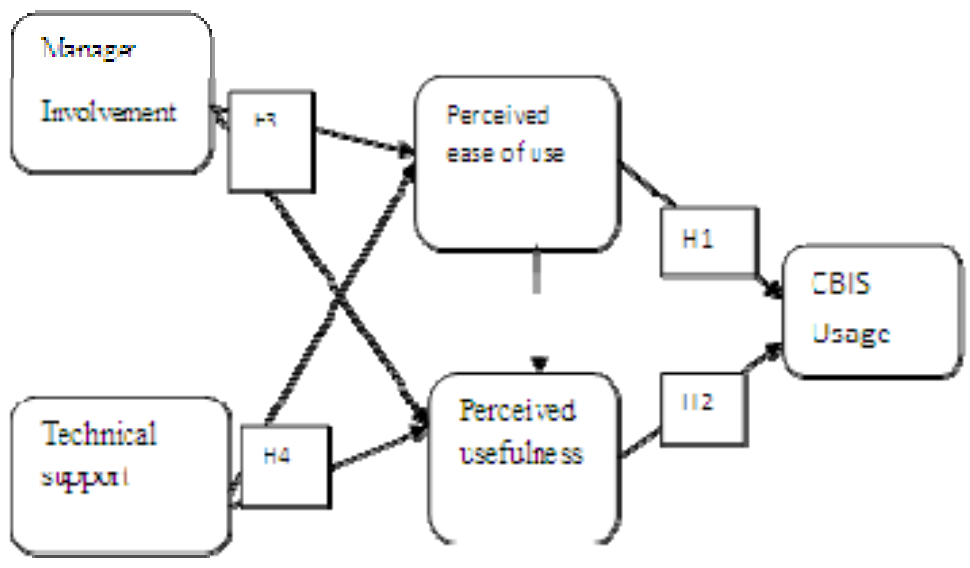

Figure 1. Research Model

The technological factors included in this study they were "manager involvement in system design and implementation" and the "availability of technical support". Manager participation in the development of the information system is the crucial element to the successful implementation of any system (King and Jaime (1971), Kling (1971), and Locander (1979)). 


\section{Macrothink}

The technical support includes the availability of support centers for manager help and directions. Researchers suggested that technical manager support is vital element that affect manager attitudes and usage of the information system (Igbaria \& Chakrabarti, 1990; Igbaria 1990; Thompson et al., 1991; Trevino \& Webster 1992; Conger, 1992, 1993; and Clegg et al., 1997).

\section{PEOU}

Many researchers have reported that PEOU influence on usage intention, either directly or indirectly (Venkatesh \& Davis, 1996; Venkatesh \& Morris, 2000; Venkatesh, 2000; Wang, Wang, Lin, \& Tang, 2003; Kerem, \& Nilsson , 2005; Guriting \& Ndubisi, 2006; Chen \& Barnes, 2007; Hernandez \& Mazzon, 2007; Eriksson, Chen, \& Barnes ,2007).

Therefore, following research hypotheses has been formulated:

Hypothesis 1: Perceived Ease of using computer- based information system is positively related to its usage by manager in Sudanese banks.

\section{PU}

Studies have demonstrated that PU is an imperative antecedent of computer utilization and the strongest of the two TAM variables (Davis, Bagozzi, \& Warshaw, 1989; Davis, Bagozzi, \& Warshaw, 1992; Taylor \& Todd, 1995; Igbaria \& Iivari, 1995; Keil et al., 1995; Satzinger \& Olfman, 1995; Igbaria et al., 1996). Thus the hypothesis of the research was stated as follows:

Hypothesis 2: Perceived usefulness of computer- based information system is positively related to its usage by managers in Sudanese banks.

\section{Manager Involvement in System Design and Implementation:}

Manager involvement in developing information systems is an important factor for successful information technology initiatives (Grover, Jeong, and Segars (1995); Wixom, and Watson (2001); and Jiang, Chen, and Klein (2002)). According to Dillon (2001) user involvement correlates with acceptance of new technology. Thus the third hypothesis of this research was formulated as follows:

Hypothesis 3: Perceived ease of using computer- based information system by banks' managers (PEOU) is positively correlated with the level of manager involvement in the system design and implementation stages.

Hypothesis 4: Perceived usefulness of using computer-based information system (PU) is positively correlated with the level of manager involvement in the system design and implementation stage.

\section{Technical Support:}

According to Choo (2002) technical support evaluates the extent to which the organization providing help and directions to use information system to managers by investing in objective resources. Availability of technical support may ease managers' worries about the complexity and security of the information technology and promote managers' willingness to accept and use it (Sun \& Zhang, 2007). Technical manager support has been suggested as an imperative facilitator for manager attitudes and subsequent awareness and usage of the system (Igbaria \& Chakrabarti, 1990; Conger, 1992; Trevino \& Webster, 1992; Igbaria 1993; Clegg et al., 
1997). Some researchers have found positive relationships between manager acceptance and various technical supports (e.g. Mirani \& King, 1994; Igbaria et al., 1997). Therefore, the fourth hypothesis of the research was stated as follows:

Hypothesis 5: Perceived Ease of Using computer- based information system by managers (PEOU) is positively correlated with the availability of technical support.

Hypothesis 6: Perceived usefulness of Using computer-based information system (PU) is positively correlated with the availability of technical support.

\subsection{Population and Sample}

This study covered 15 Sudanese commercial banks in Khartoum State and Gezira State in Sudan, selected on a stratified random sampling basis. The selected banks included three government owned banks, one privately owned bank, and 13 joint ventures banks.

From 180 middle level managers in the selected banks, 150 managers were selected randomly to represent the research sample. Where the questionnaire survey was used to collect the research data and achieving a response rate of $75 \%$. Most of the respondents surveyed were male $(87.8 \%)$ as compared to female respondents $(12.2 \%)$. The largest percentage age of the sample population (37.5\%) is aged more than 46 years old, followed by the age group 36 to 40 years $(30 \%)$. Only three respondents $(2.5 \%)$ were less than 25 years old.

\subsection{Measure}

A structured questionnaire was used in this study to collect data from middle level managers in the selected banks. There were five sections in the questionnaire: CBIS usage, perceived ease of use, perceived usefulness, manager involvement, and finally technical support. The study derived measurements of items from related previous studies of information systems. Items adapted from Davis, Bagozzi, and Warshaw (1989); Davis and Venkatesh (1996); Adams, Nelson, and Todd (1992); Doll, Hendrickson, and Deng, (1998) were used to measure PEOU and PU. Three items adapted from Doll and Tokzadeh's (1988) and Davis's (1989) were used to operationalize manager involvement. Three items adapted from Igbaria (1990, Thompson et al. (1991); an Trevino and Webster (1992) were used to operationalize technical support. A five -point Likert-scale was used to represent the responses of the research subjects.

\section{Results}

The data collected were coded and analyzed using the Statistical Package for Social Science Studies (SPSS). Coefficient alpha $\alpha$ was used to assess the reliability of all scales.

Table 1 . Reliability analysis

\begin{tabular}{ll}
\hline Factor & Coefficient alpha \\
\hline PEOU & 0.74 \\
PU & 0.77 \\
Manager involvement & 0.70 \\
Technical support & 0.83 \\
\hline
\end{tabular}


All scales indicated moderate reliability (Ramaprasad, 1987), ranging from 0.70 for manager involvement to 0.83 for technical support (Table 1). It should be noted that all coefficient alpha values did not surpass Nunnally's (1967) generally accepted alpha level of 0.70 .

\subsection{Model Testing Results}

Table 2. Regression of PEOU and PU on CBIS usage

\begin{tabular}{|c|c|c|c|c|c|c|}
\hline $\begin{array}{l}\text { Explanatory } \\
\text { variable }\end{array}$ & $\begin{array}{l}\text { Estimated } \\
\text { Coefficient }\end{array}$ & $\begin{array}{l}\text { Sig. } \\
\text { Level }\end{array}$ & $\mathrm{R}^{2}$ & $\overline{\mathrm{R}}^{2}$ & $\mathrm{~F}$ & $\begin{array}{l}\text { Sig. } \\
\text { Level }\end{array}$ \\
\hline \multirow[t]{2}{*}{ PEOU } & 0.450 & 0.000 & & & & \\
\hline & $(\mathrm{t}=4.85)$ & & 0.830 & .82 & 197.85 & $1 \%$ \\
\hline PU & $\begin{array}{l}0.490 \\
(t=5.25)\end{array}$ & 0.000 & & & & \\
\hline
\end{tabular}

The Ordinary Least Square (OLS) estimates of the relationship between CBIS usage and the "PEOU" and "PU" of the system are reported in Table (2) above, where the figures inside the brackets are the t-ratios of the estimated coefficients. It is observed from the table that the overall relationship is significant at the $1 \%$ level, and that the estimated coefficients are highly significant. Furthermore, the value of $\mathrm{R}^{2}$ suggests that the explanatory variables (PEOU and PU) explain $83.0 \%$ of the variations in CBIS usage.

Table 3. Regression of technological factors on PEOU

\begin{tabular}{llllllll}
\hline $\begin{array}{l}\text { Explanatory } \\
\text { variable }\end{array}$ & Construct & $\begin{array}{l}\text { Estimated } \\
\text { Coefficient }\end{array}$ & $\begin{array}{l}\text { Sig. } \\
\text { Level }\end{array}$ & $\mathrm{R}^{2}$ & $\overline{\mathrm{R}}^{2}$ & $\mathrm{~F}$ & $\begin{array}{l}\text { Overall } \\
\text { Sig. } \\
\text { Level }\end{array}$ \\
\hline \multirow{4}{*}{ PEOU } & $\begin{array}{l}\text { Manager } \\
\text { involvement }\end{array}$ & 0.623 & & & & \\
& Technical & 0.320 & & & & & \\
& support & $(\mathrm{t}=4.218)$ & & & & & \\
& Manager & 0.359 & & & & & \\
PU & involvement & $(\mathrm{t}=3.867)$ & 0.000 & 0.121 & 0.102 & 14.318 & $1 \%$ \\
& Technical & 0.257 & & & & & \\
& support & $(\mathrm{t}=0.277)$ & & & & & \\
\hline
\end{tabular}

Table (3) above reports regression results, where the technological factors, namely "manager involvement" and "technical support", are regressed on PEOU and PU. It is clear from these results that technological factors explain $80.7 \%$ of the variation in PEOU, and the 
relationship is significant at the $1 \%$ level. It is also observed that, although both variables are equally significant in explaining PEOU, yet manager involvement seems to have a greater effect (with an estimated coefficient of 0.623) compared to technical support (with an estimated coefficient of 0.320). Results in the table depict a significant relationship between PU and technological factors. At significance level 1\% manager involvement and technical support explain $10.2 \%$ of variation in $\mathrm{PU}$

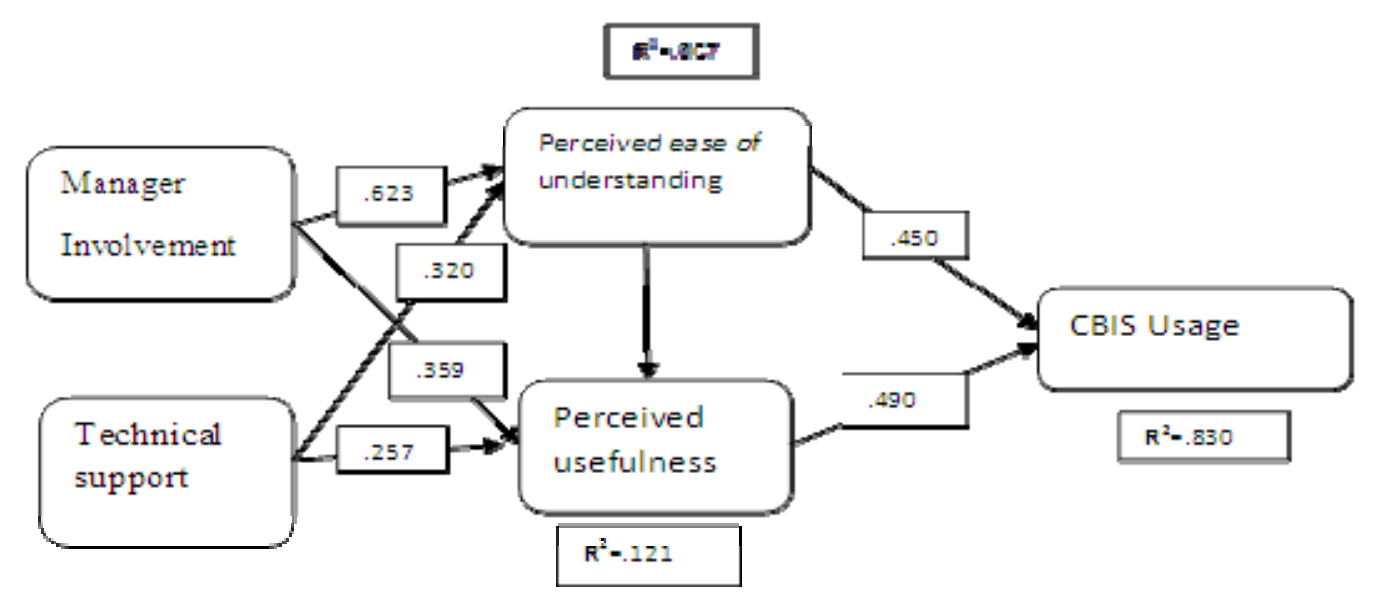

Figure 2. Results of Model Test

Table 4. Model goodness of fit

\begin{tabular}{lllll}
\hline Model path & $\chi 2$ & $\mathrm{df}$ & $\chi 2 \backslash \mathrm{df}$ & Sig. leve \\
\hline Path one & 21.440 & 8 & 2.68 & .003 \\
Path two & 29.944 & 8 & 3.74 & .000 \\
\hline
\end{tabular}

Table (4) above represents the results of hypothesis (3) and (4) through examining the two main paths of the research model. The first path estimated that PEOU and PU mediates the relationship between "manager involvement" and "CBIS", $(\chi 2=21.440, \mathrm{df}=12, \mathrm{p}<.05)$ which support the fitness of the model. The first path of the model was then compared with the second path (Figure 2) where a direct and also mediated relationship existed between technical support and CBIS usage. This relationship is mediated through PU and PEOU $(\chi 2$ $=29.944, \mathrm{df}=12, \mathrm{p}<0.05)$ and the data fit the model well.

\section{Discussion}

This study is aimed at figuring out the influence of technological factor on CBIS usage by middle level managers in Sudanese banks. It may be noted that results of testing hypothesis (1) and (2) showed that PEOU and PU had significant effect on CBIS usage. These results are in agreed with the findings of many previous studies Davis, Bagozzi, and Warshaw (1989), Mathieson (1991), Igbaria et al. (1997), and Ndubisi et al. (2001). However, these results are also in disagree with the findings reported by Brown (2002). The differentiating higher 
influence of PU on CBIS usage (0.490) compared to the lower impact of PEOU (0.450) may recommend that managers in banks are more prone to utilize CBIS in light of their handiness for their work rather than for its easiness. Managers who are unaware of the benefits of CBIS to their work they are unlikely to use such a system. This argument raise the importance of job- system fit which can be considered through managers involvement in the process of system designing and implementations.

Results demonstrated that PEOU and PU, fully mediate the influence of "manager involvement in system designing and implementation" and "technical support" on CBIS usage. These outcomes affirmed hypothesis (3) and (4). This implies if managers were involved in the design and implementation of the systems they are likely perceived the system as easy, friendly, and useful for their work, and they likely to use.

\section{Conclusion}

In the light of the above results, it may be concluded that in the context of banks in Sudan, strong statistical evidence has been cited in support of the entire set of hypotheses stated by the research. In particular managers' usage of computer - based information systems is affected directly by their perceived ease of using a system and the perceived usefulness of the system. While computer - based information system usage is indirectly influenced by the manager involvement in system design and implementation as well as availability of technical support in the bank.

The study reflects the influence of technological factors on computer - based information systems usage in the context of the banking sector in Sudan. Therefore, its results can be considered as starting point for assessing the influence of these factors in other sectors in Sudan and in other developing countries.

The results of this study, also, have important implications for both research and practice. The results of this research should provide better understanding of the variables associated with the usage of a computer-based system. The practical implication is that more technological support is needed to promote managers CBIS usage. In other words, since this study showed how technological factors can influence CBIS usage at the individual level; these factors should be emphasized when promoting managers usage of certain information system.

This study is not without limitation. Besides, investigating technological factors, other factors influencing CBIS usage may also need to be examined. Features, such as organizational factors and individual factors are external factors that are equally important in promoting CIBS usage the organizations. Future studies should consider these attributes in order to look at CBIS in a more meaningful way. Finally, this study was conducted in the banking sector setting; hence, future studies should consider other sectors.

\section{References}

Adams, D. A., Nelson, R. R., \& Todd, P. A. (1992). Perceived usefulness, perceived ease of use, and manager acceptance of information technology: A replication. MIS Quarterly, 16, 227-247. http://dx.doi.org/10.2307/249577

Agarwal, R., \& Parsad, J. (1999). Are individual differences germane to the acceptance of new information technologies? Decision Sciences - Business Publications. 
Bucciarelli, L. L. (1994). Designing engineers. MIT press.

Chen, Y. H., \& Barnes, S. (2007). Initial trust and online buyer behavior. Ind. Manage. Data Syst, 107, 21-36. http://dx.doi.org/10.1108/02635570710719034

Choo, C. W. (2002). Information Management for the Intelligent Organization: The Art of Scanning the Environment (3rd ed.). Medford, NJ: Information Today, Inc.

Davis, F. D. (1986). A technology acceptance model for empirically testing new end user information systems: Theory and results. Sloan School of Management, M.I.T.

Davis, F. D. (1989). Perceived Usefulness, Perceived Ease of Use and User Acceptance of Information Technology. MIS Quarterly, 13, 319-340. http://dx.doi.org/10.2307/249008

Davis, F. D., Bagozzi, R. P., \& Warshaw, P. R. (1989). User acceptance of Computer Technology: A Comparison of two theoretical models. Management Science, 35. http://dx.doi.org/10.1287/mnsc.35.8.982

Delone, W. H., \& Mclean, E. R. (1992). Information systems success: The quest for The Dependent variable. Information Systems Research, 3, 60-95. http://dx.doi.org/10.1287/isre.3.1.60

Dillon, A. (2001). User Acceptance of Information Technology. In W. Karwowski (Ed.). Encyclopedia of Human Factors and Ergonomics. London: Taylor and Francis.

Doll, W. J., Hendrickson, A., \& Deng, X. (1998). Using Davis's perceived usefulness and ease-of-use instrument for decision making: A confirmatory and multi group invariance $\begin{array}{llll}\text { analysis. } & \text { Decision } & \text { Sciences, } & 29,\end{array}$ http://dx.doi.org/10.1111/j.1540-5915.1998.tb00879.x

Elbeltagi, I., McBride, N., \& Hardaker, G. (2002). Evaluating The Factors Affecting DSS Usage By Senior Managers In Local Authorities In Egypt.

Holmes, F. F. (1978). The filany Roles of the User in Eystems Development. Data Base, 9.

Hussein, R., \& Selamat, H. (2005). The Impact of Technological Factors on Information Systems Success in the Electronic government Context. The Second International Conference on Innovations in Information Technology (IIT'05).

William, B., Locander, H., Albert, N., \& Richard, W. S. (1979). A Team Approach to Managing the Development of a Decision Support System. MIS Quarterly, 3, 53-63. http://dx.doi.org/10.2307/249148

Igbaria, M., \& Chakrabarti, A. (1990). Computer Anxiety and Attitudes Towards Microcomputer Use. Behaviour and Information Technology, 9, 229-241. http://dx.doi.org/10.1080/01449299008924239

Isaac, S., \& Michael, W. (1990). Handbook in research and evaluation: For education and the behavioral sciences (2nd ed.). San Diego, CA: EdiTS Publishers.

Ivanz \& Fink, D. (2006). Information Systems Success in the Public Sector: Stakeholders' 
Perspectives and Emerging Alignment Model. Issues in Informing Science and Information Technology, 3 .

Kawu, H. (2009). The Impact of Information Technology on the Bank Performance (Nigeria In Perspectives).

Keil, M., Beranek, P. M., \& Konsynski, B. R. (1995). Usefulness and Ease of Use Field-Study Evidence Regarding Task Considerations. Decision Support Systems, 13(1) 75-91. http://dx.doi.org/10.1016/0167-9236(94)E0032-M

Keen, G., Peter, W. \& Elihu, M. G. (1977). The Politics of Software Systems Design. Datamation, 80-84.

Kling, R. (1971). The Organizational Context of User-Centered Software Design. MIS Quarterly, 1, 41-52. http://dx.doi.org/10.2307/249021

Kimble, C., \& McLoughlin, K. (1995). Computer Based Information Systems and Managers Works. New Technology, Work and Employment, 10, 56-67. http://dx.doi.org/10.1111/j.1468-005X.1995.tb00005.x

Mathieson, K. (1991). Predicting user intentions: comparing the technology acceptance model with the theory of planned behavior. Information Systems Research, 2, 173-191. http://dx.doi.org/10.1287/isre.2.3.173

Mendenhal, W., \& Sincich, T. (1993). Second Course in Business Statistics: regression analysis. Dellen/Macmillian, New York.

Milicic, M. (1998). A case study of IT exploitation towards Developing new IT culture. International Federation of Automatic Control, IFAC.

Moon, J. W., \& Kim, Y. G. (2001). Extending the TAM for a world-wide-web context. Information Management, 38, 217-230. http://dx.doi.org/10.1016/S0378-7206(00)00061-6

Orlikowski, W. J., \& Barley, S. R. (2001). Technology and Institutions - What Can Research on Information Technology and Research on Organizations Learn from Each Other. MIS Quarterly, 25, 145-165. http://dx.doi.org/10.2307/3250927

Ramaprasad, A. (1987). Cognitive Process as a Basis for MIS and DSS Design. Management Science, 33, 2139-148. http://dx.doi.org/10.1287/mnsc.33.2.139

Ravicandran \& Banerjee. (2002). project leadership on eventual outcome, Project Management Institute. Project Management Journal, 32, 49-55.

Satzinger, J. W., \& Olfman, L. (1995). Computer support for group work: Perceptions of the usefulness of support scenarios and end-user tools. Journal of Management Information Systems, 11, 115-148.

Seddon, P. B., \& Kiew, M. Y. (1996). A partial test and development of DeLone and McLean's model of IS success. Australian Journal of Information Systems, 4, 90-109. http://dx.doi.org/10.3127/ajis.v4i1.379 


\section{Macrothink}

Journal of Social Science Studies

ISSN 2329-9150

2016, Vol. 3, No. 1

Sun, H., \& Zhang, P. (2006). Applying Markus and Robey's Causal Structure to Examine User Technology Acceptance Research: A New Approach. Journal of Information Technology Theory and Application (JITTA), 8, 21-40.

Taylor, S., \& Todd, P. A. (1995). Understanding Information Technology Usage: A Test of Competing Models. Information Systems Research, 6, 144-176. http://dx.doi.org/10.1287/isre.6.2.144

Thompson, R., Higgins, C., \& Howell, J. (1991). Personal computing: Toward a conceptual model of utilization. MIS Quarterly, 15, 125-143. http://dx.doi.org/10.2307/249443

Trevino, K., \& Webster, J. (1992). Flow in Computer-mediated Communication. Communication Research, 19, 539-573. http://dx.doi.org/10.1177/009365092019005001

Venkatesh, V., \& Morris, M. G. (2000). Why don't men ever stop to ask for directions? Gender, social influence, and their role in technology acceptance and usage behavior. MIS Quarterly, 24, 115-139. http://dx.doi.org/10.2307/3250981

\section{Copyright Disclaimer}

Copyright for this article is retained by the author(s), with first publication rights granted to the journal.

This is an open-access article distributed under the terms and conditions of the Creative Commons Attribution license (http://creativecommons.org/licenses/by/3.0/). 